\title{
Antitumor imidazotetrazines. 38. New 8-substituted derivatives of the imidazo[5,1-d]-1,2,3,5-tetrazines temozolomide and mitozolomide
}

\author{
David A. F. Langnel, Jillian Arrowsmith, and Malcolm F. G. Stevens* \\ Cancer Research Laboratories, School of Pharmaceutical Sciences, University \\ of Nottingham, University Park, Nottingham NG7 2RD, UK \\ E-mail:malcolm.stevens@nottingham.ac.uk
}

(received 09 Mar 00; accepted 20 Aug 00; published on the web 28 Aug 00)

\begin{abstract}
The imidazo[5,1-d]-1,2,3,5-tetrazine ring-system is hypersensitive to attack by nucleophiles. Therefore, acidic conditions were applied successfully to synthesise new 8-substituted derivatives of the antitumor agents temozolomide (1a) and mitozolomide (1b). The 8-cyanoimidazotetrazines (7a, b) were prepared by dehydration of temozolomide and mitozolomide with thionyl chloride and $7 \mathrm{~b}$ was converted to the corresponding 8-thioamide (9) with thioacetamide in DMF-HCl. Generation of tertiary carbocations from substituted alkenes by concentrated $\mathrm{H}_{2} \mathrm{SO}_{4}$ in the presence of 8-cyanoimidazotetrazines afforded secondary amide congeners (13, 14) of imidazotetrazine-8-carboxamides (Ritter reaction). Peptidic-type coupling of imidazotetrazine-8-carboxylic acids $(15 \mathrm{a}, \mathrm{b})$ with the protected hydrazine reagent, $t$-butylcarbazate $\left(\mathrm{BOC}-\mathrm{NHNH}_{2}\right)$, followed by acidic deprotection, gave salts of the carbohydrazides $(17,18)$ which could be derivatised with aromatic aldehydes. Attempts to synthesise the unknown 8-aminoimidazotetrazine (24) from appropriate 8-substituted substrates by modifications of Hofmann, Curtius and Lossen rearrangements under acidic conditions were all unsuccessful.
\end{abstract}

Keywords: Imidazotetrazines, Ritter reaction, peptidic coupling, $t$ carbohydrazides 


\section{Introduction}

The antitumor imidazotetrazine temozolomide (1a) has been launched on the market under the brand name Temodal ${ }^{\circledR}$ in Europe and Temodar ${ }^{\circledR}$ in the USA for the treatment of certain brain tumors; desirable features of the drug include its oral bioavailability and a favourable side-effect profile. ${ }^{1}$ The drug undergoes ring-opening at physiological $\mathrm{pH}$ to generate the corresponding open chain monomethyltriazene (MTIC; 2) which then undergoes proteolytic decomposition to 5-aminoimidazole-4-carboxamide (AIC; 3) and the electrophilic methanediazonium reactive species (4). The cytotoxic event is the methylation of guanine residues of DNA (5) at the $\mathrm{O}(6)$ position (Scheme 1) leading to the incorporation of the mispairing base $\mathrm{O}^{6}$-methylguanine (6). ${ }^{2}$ The 3-(2-chloroethyl)-derivative (mitozolomide; 1b), a DNA cross-linker and the most potent of the imidazotetrazines in preclinical evaluations, induced life-threatening bone-marrow suppression in patients and was withdrawn from clinical trial. ${ }^{3}$ The 3-benzyl- (1c) and 3-ethyl-analogues (1d) were devoid of antitumour activity in experimental systems. ${ }^{4}$

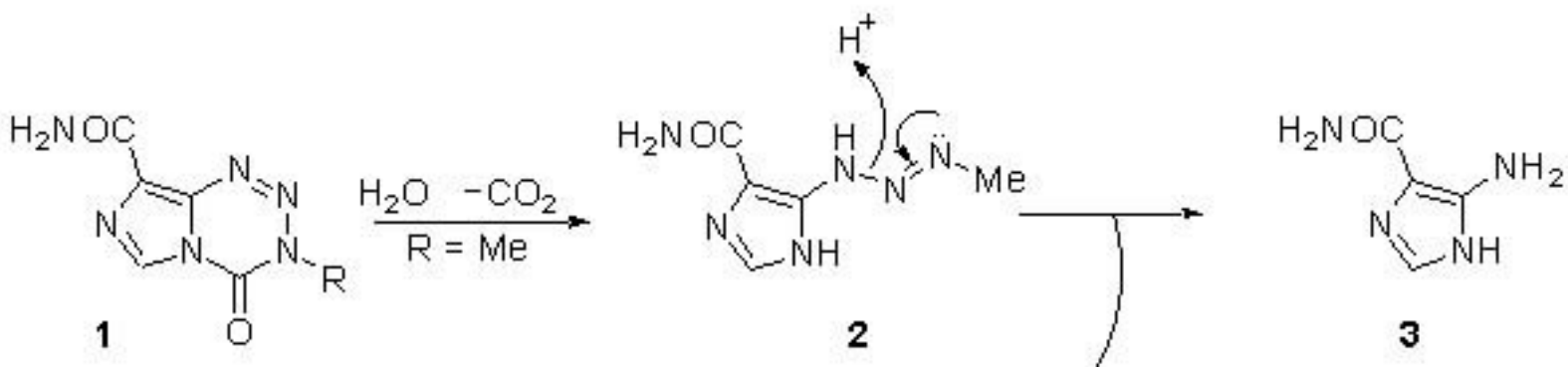
a: $\mathrm{R}=\mathrm{Me}$ (temozolomide)
b: $\mathrm{R}=\left(\mathrm{CH}_{2}\right)_{2} \mathrm{Cl}$ (mitozolomide)
c: $\mathrm{R}=\mathrm{Bn}$
d: $R=E t$<smiles>COc1nc(N)nc2c1ncn2[18OH]</smiles>

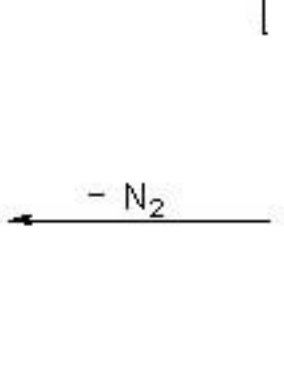

6

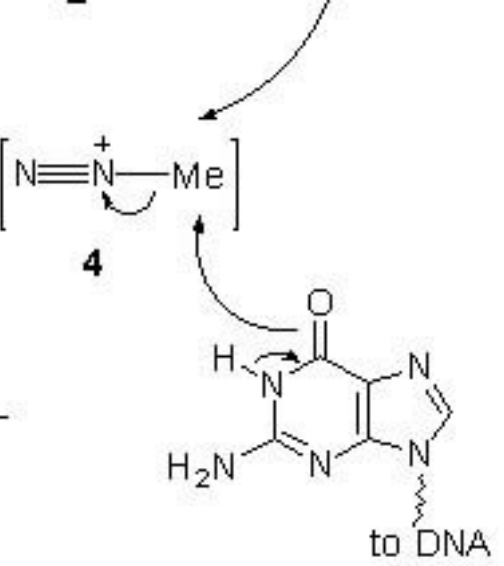

5

\section{Scheme 1}


One approach to extend the clinical spectrum of action of temozolomide has concentrated on modifying the DNA-binding signature of the imidazotetrazines by adaptation of the 8-carboxamide group. Many factors might play a role on the activity of C-8 modified imidazotetrazines. The C-8 moiety could be involvedin: (i) modifying the transport properties of the bicyclic systems; (ii) perturbing the initial non-covalent encounter between the intact (prodrug) imidazotetrazine and guanine sequences in DNA; (iii) exerting kinetic control of the activating ring-opening reaction; and (iv) stabilizing the ring-opened triazene intermediates. Accordingly, structureactivity relationships for $\mathrm{C}(8)$ derivatives of the 3-(2-chloroethyl) series are complex to interpret. The $8-N$-methyl-carboxamide was equiactive with the parent carboxamide (1b), but activity decreased as the bulk of $N$-alkyl substitution increased. Replacement of the 8 -carboxamide residue with sulphonamide, $\mathrm{N}$-alkylsulphonamide, sulphoxide and sulphone residues led to highly active compounds: conversely, activity was lost in the case of the 8phenyl, 8-cyano and 8-nitro derivatives and the 8-carboxylic acid, 8-esters and 8 -thioesters wereonly active at toxic doses. ${ }^{5}$ Temozolomide and mitozolomide have been conjugated through the carboxylic function to heterocyclic $\mathrm{H}$ bonding motifs and spermidine ${ }^{6}$ and linked to peptides and lexitropsins by solid state automated chemistry. ${ }^{7}$ Peptidic motifs which recognise AT sequences in the minor groove of DNA (eg. SPPK-SPPK-NH $\mathrm{NH}_{2}$, the tandem repeat of the histone DNA-binding motif, or PRGRP, a fragment of the nonhistone chromosomal protein HMG-I/Y) or the major groove (eg. the guaninebinding tryptophan-containing tetrapeptide $\mathrm{WDGW}-\mathrm{NH}_{2}$, or the helix fragment of the trp repressor IATITGSN-NH$H_{2}$ ) have been linked to temozolomide and mitozolomide. ${ }^{8}$ Unexpectedly, DNA alkylation patterns of all conjugates were nearly identical to those elicited by the unconjugated imidazotetrazines, indicating that covalent modification of DNA was restricted to guanine sites in the major groove, irrespective of the putative targeting property of the peptidic ligand.

In the present work we have returned to business left unfinished in our original work on imidazotetrazines in the 1980s. We now report chemistries exploiting the acid stability of the tetrazine ring which have allowed us to access further novel $\mathrm{C}(8)$ modifications of imidazotetrazines (1). 


\section{Results and Discussion}

8-Cyano-imidazotetrazines. The cyano analogues (7a) and (7b) of temozolomide and mitozolomide have been prepared previously from the unstable 4-cyano-5-diazoimidazole and methyl ${ }^{9}$ and 2-chloroethyl isocyanates, ${ }^{5}$ respectively. Attempted dehydration of the carboxamide residue of $1 \mathrm{a}$ with $\mathrm{P}_{2} \mathrm{O}_{5}$ alone, or in methanesulphonic acid at temperatures $>85{ }^{\circ} \mathrm{C}$, led to decomposition of the tetrazine ring; similarly decomposition ensued under Swern oxidation conditions and following interaction of $1 \mathrm{a}, \mathrm{b}$ with benzenesulphonyl chloride in pyridine.

More successful was the formation of the nitrile (7a) (59\%) from 1a in $\mathrm{POCl}_{3}$ at $90{ }^{\circ} \mathrm{C}$. Optimum conversion of carboxamides ( $\left.1 \mathrm{a}-\mathrm{d}\right)$ to nitriles $(7 \mathrm{a}-\mathrm{d})$ was achieved in thionyl chloride-DMF at $60{ }^{\circ} \mathrm{C}$, the cyano analogues of temozolomide (7a) and mitozolomide (7b) being obtained in 85 and $49 \%$ yields, respectively. Similarly, the bis(imidazotetrazine)-dicarboxamide $(8 \mathrm{a})^{10}$ afforded the corresponding dinitrile (8b) (55\%) in thionyl chloride-DMF. Interestingly, 7 a was also formed (35\%) from temozolomide and formic acidacetonitrile in the presence of paraformaldehyde. This transamidation reaction is mechanistically intriguing: it has been reported as a general method for dehydrating alkyl- and arylamides ${ }^{11}$ requiring formal transfer of water from the amide (ie 1a) to solvent (acetonitrile) with the aldehyde serving as a relay for the water transfer.

8-Thiotemozolomide (9). Temozolomide was recovered following attempted direct thionation with $\mathrm{P}_{2} \mathrm{~S}_{5}$ in THF, toluene or xylene, or from Lawesson's reagent in HMPA at temperature $<80{ }^{\circ} \mathrm{C}$. With the more soluble Belleau's reagent in DCM at room temperature a small yield (10\%) of the yellow 8thiotemozolomide (9) was isolated.

Conversion of nitriles to thioamides with hydrogen sulphide is a standard process but typically requires the presence of bases, conditions inimical to tetrazine ring integrity. Cyanotemozolomide (7a) was recovered from attempted thionation using hydrogen sulphide in DMF at $45-65{ }^{\circ} \mathrm{C}$; above $65{ }^{\circ} \mathrm{C}$ decomposition of substrate was observed. More success attended thionations conducted in strongly acidic conditions: conversion of 7 a to thiotemozolomide (9) employing thiolacetic acid in 10M-hydrochloric acid $(27 \%$ yield) was improved (to 49\%) using a thioacetamide-DMF reaction medium saturated with $\mathrm{HCl}$ gas. 


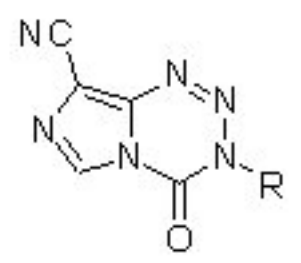

$$
\begin{aligned}
& 7 \\
& \text { a: } \mathrm{R}=\mathrm{Me} \\
& \text { b: } \mathrm{R}=\left(\mathrm{CH}_{2}\right)_{2} \mathrm{Cl} \\
& \text { c: } \mathrm{R}=\mathrm{Bn} \\
& \text { d: } \mathrm{R}=\mathrm{Et}
\end{aligned}
$$<smiles>[R]c1ncn2c(=O)n(Cc3cccc(Cn4nnc5c([R])ncn5c4=O)c3)nnc12</smiles>

\section{8}

a: $\mathrm{R}=\mathrm{CONH}_{2}$

b: $\mathrm{R}=\mathrm{CN}$<smiles>Cn1nnc2c(C(N)=S)ncn2c1=O</smiles><smiles>C=C</smiles><smiles>Cn1nnc2c(C(=N)S)ncn2c1=O</smiles>

The ${ }^{1} \mathrm{H}$ NMR spectrum of 8 -thiotemozolomide was comparable to that of temozolomide in the chemical shifts of the imidazole and methyl protons: however two exchangeable protons at $\mathrm{d} 9.47$ and 9.94 suggest that 9 exists in the imino-thiol tautomeric form (cf. the two NH absorptions in temozolomide at $\mathrm{d} 7.68$ and 7.81 which are characteristic of primary carboxamides).

Secondary amide derivatives of imidazotetrazines (13) and (14). $\mathrm{N}$ substituted derivatives of the 8-carboxamide group of imidazotetrazines have been prepared from the corresponding 8 -acid chlorides and amines. ${ }^{12}$ However this route suffers the disadvantage that stoichiometric precision in the incorporation of the amine component is required to avoid base-induced degradation of the bicyclic nucleus. In the present work we have adapted the Ritter reaction (the electrophilic addition of olefins to nitriles under acidic conditions) to yield secondary amides after hydrolysis. A mixture of 
concentrated $\mathrm{H}_{2} \mathrm{SO}_{4}$ in acetic acid was used both as a reactant, to generate carbocations, and as a solvent in which the imidazotetrazines were stable and soluble.

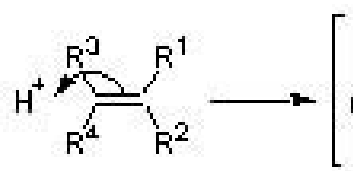

10

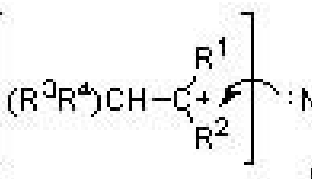

11<smiles>[R]n1nnc2c(C#N)ncn2c1=O</smiles>

7

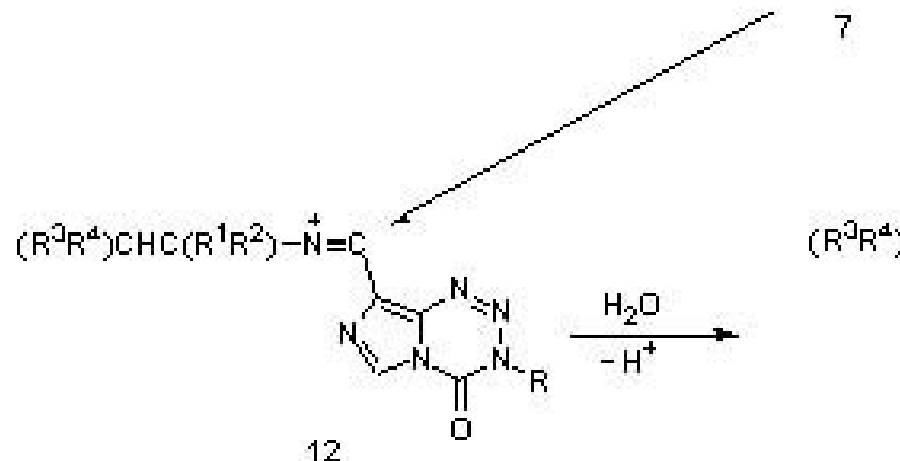

12

\begin{tabular}{|c|c|c|c|c|}
\hline $\mathrm{R}$ & $\mathrm{R}^{1}$ & $\mathrm{R}^{2}$ & $\mathrm{R}^{\mathrm{a}}$ & $\mathrm{R}^{4}$ \\
\hline Me & Me & $n-\mathrm{Pr}$ & $\mathrm{H}$ & $\mathrm{H}$ \\
\hline Me & Me & $n-B$ ut & $\mathrm{H}$ & $\mathrm{H}$ \\
\hline We & Me & $n$-Pent & $\mathrm{H}$ & $\mathrm{H}$ \\
\hline Me & Me & Et & Me & $\mathrm{H}$ \\
\hline Me & Me & Mue & Me & Me \\
\hline$\left(\mathrm{CH}_{2}\right)_{2} \mathrm{Cl}$ & Me & $n-P r$ & $\mathrm{H}$ & $\mathrm{H}$ \\
\hline Bn & Me & $n-\mathrm{Pr}$ & $\mathrm{H}$ & $\mathrm{H}$ \\
\hline
\end{tabular}

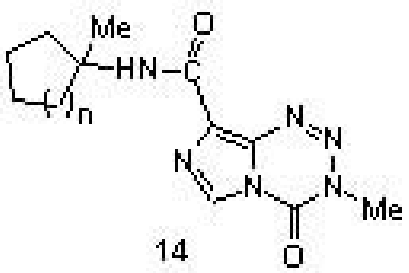

a: $n=1$

b: $n=2$

13

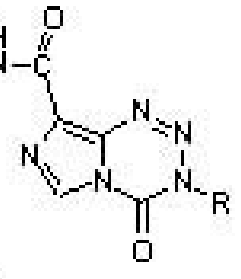


8-cyano-imidazotetrazines (7). Following water quench of the intermediate nitrilium species (12), the secondary amides (13) (Scheme 2) were formed. As expected the same amide (13a) was formed from $7 \mathrm{a}$ and 2-methyl-1-pentene (10a) or the isomeric 2-methyl-2-pentene. The reaction was also effected using $7 \mathrm{a}$ and the cyclic alkenes methylenecyclopentane and methylenecyclohexane to yield the novel cyclic amides $(14 \mathrm{a}, \mathrm{b})$, respectively.

Hydrazide Derivatives of Imidazotetrazines. A logical route to the 8 -hydrazide analogues of temozolomide and mitozolomide, from the interaction of the 8 acid chlorides and hydrazine, was thwarted by facile hydrazinolysis of the tetrazine ring. ${ }^{12}$ In the present work the 8 -acid derivatives $(15 \mathrm{a}, \mathrm{b})$ were coupled with $t$-butylcarbazate $\left(t\right.$-BOC-NHNH $\left.{ }_{2}\right)$ in the presence of benzotriazole-1-yloxytris(pyrrolidino)phosphonium hexafluorophosphate (PyBOP) and triethylamine. 

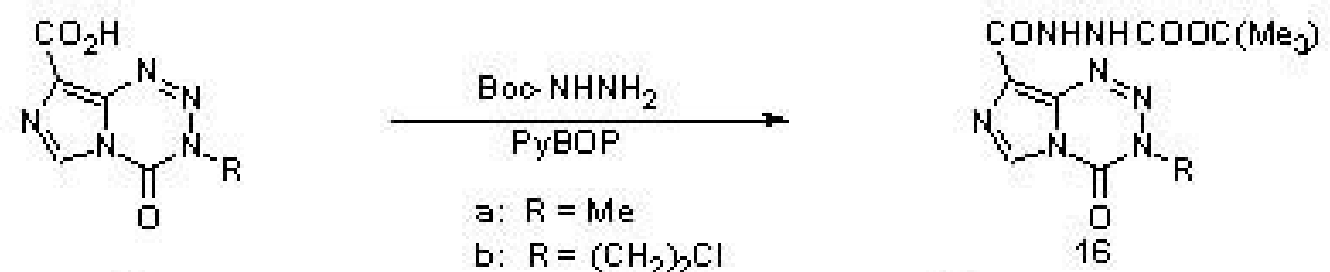

15
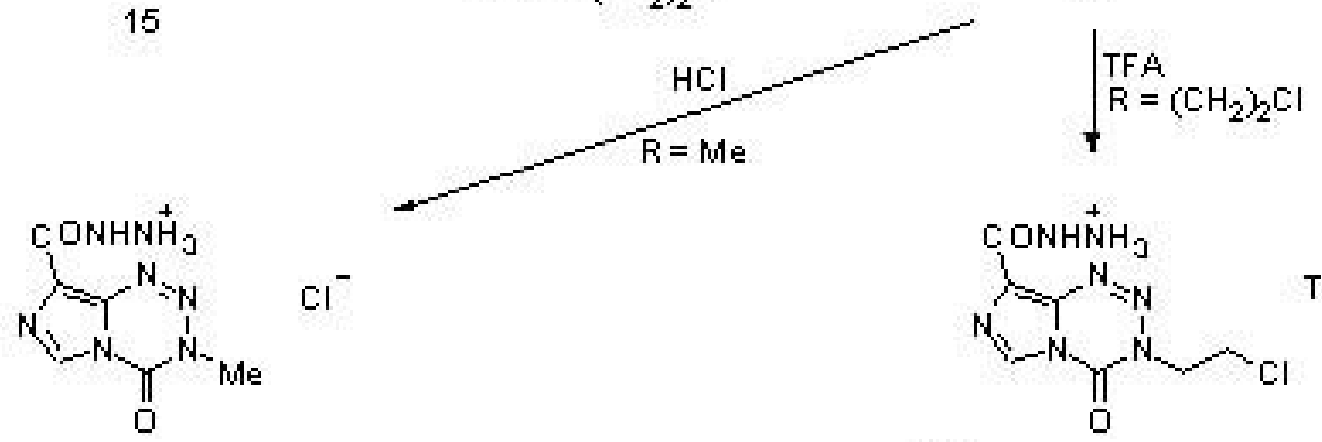

17
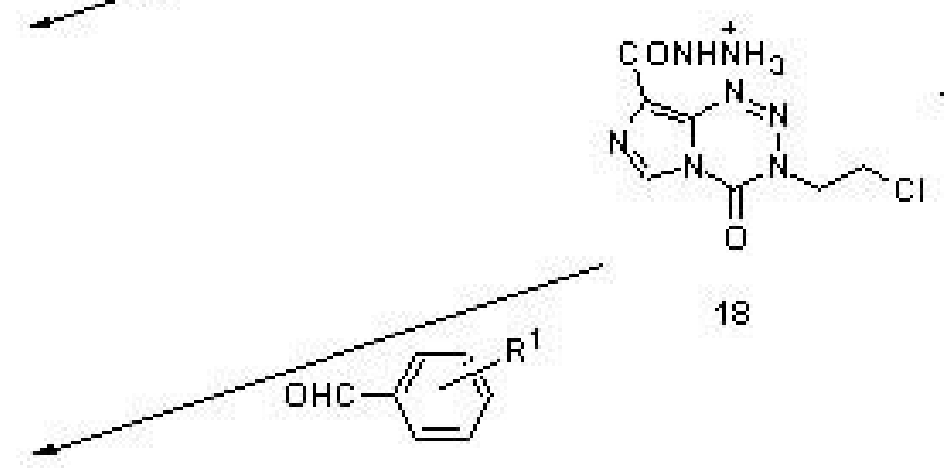

TFA ${ }^{-}$

18

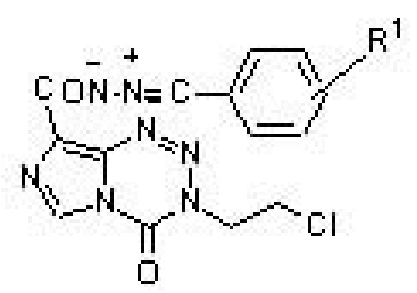

19

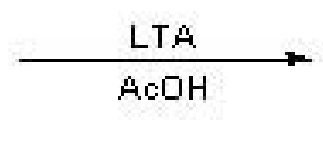

20
a: $\mathrm{R}^{1}=2-\mathrm{Cl}$
b: $\mathrm{R}^{1}=4-\mathrm{Cl}$
c: $\mathrm{R}^{1}=3-\mathrm{NO}_{2}$

\section{Scheme 3}

Cleavage of the protected hydrazides $(16 \mathrm{a}, \mathrm{b})$ with $\mathrm{HCl}$ or TFA led to the formation of the hydrochloride or trifluoroacetate salts of the hydrazides of temozolomide (17) and mitozolomide (18), respectively (Scheme 3). Surprisingly, catalytic hydrogenation of the $N$-nitroamide analogue of mitozolomide $\left(1 \mathrm{~b} ; \mathrm{X}=\mathrm{NHNO}_{2}\right.$ ) (see Scheme 4), formed by nitration of mitozolomide in a nitric-sulphuric acid mixture, ${ }^{12}$ did not produce the free base of hydrazide (18): instead, hydrogenolysis of the N-N double bond furnished only the carboxamide $\left(1 \mathrm{~b}: \mathrm{X}=\mathrm{NH}_{2}\right.$ ) (Scheme 4). Hydrazide (18) reacted with substituted benzaldehydes to yield the hydrazones (19a-c) but efforts to generate and trapdipolarreactive intermediates (20) with lead (IV) 
acetate (LTA) in acetic acid led only to recovery of unchanged carboxylic acid (15b).

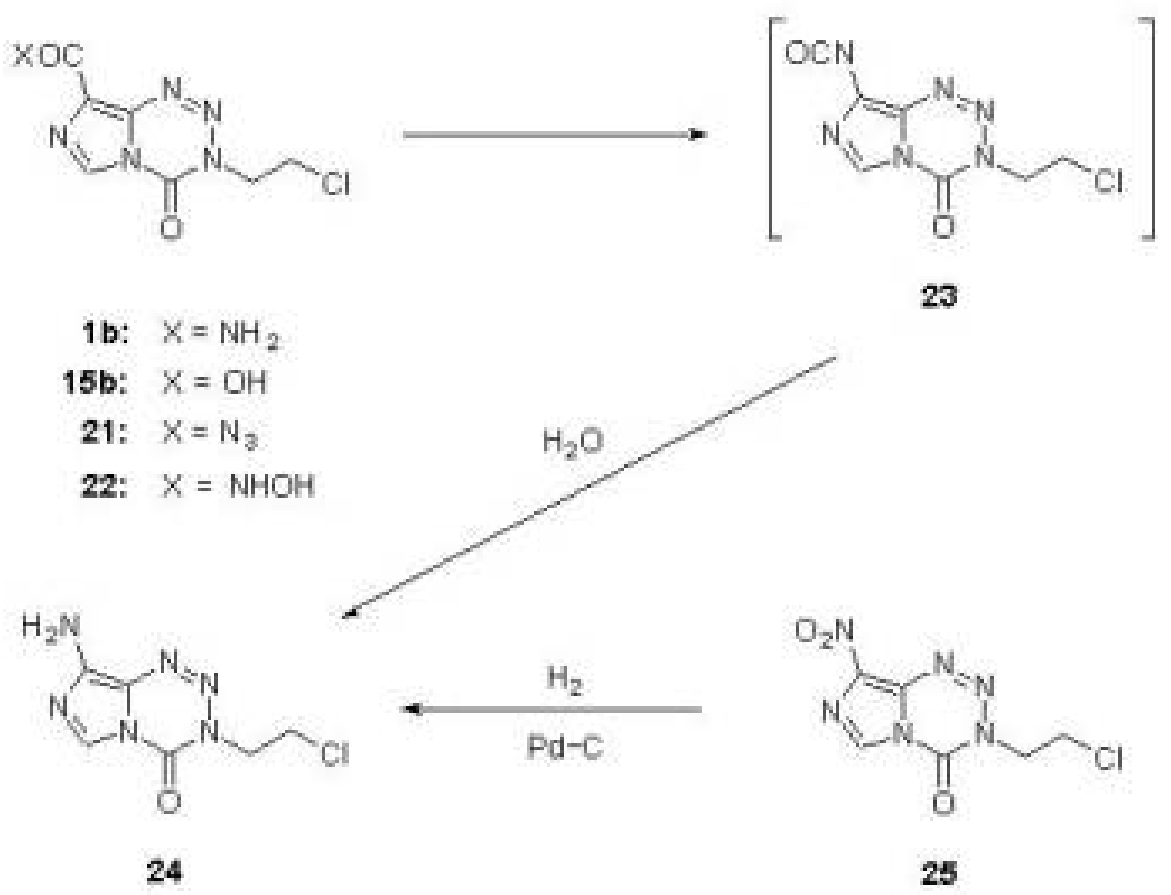

\section{Scheme 4}

Unsuccessful Routes to 8-Aminoimidazotetrazines. Furtherefforts to synthesize the potentially useful isocyanate (23), which might have provided a source of the elusive 8-amino-imidazotetrazine (24), were unsuccessful. Attempted Hofmann rearrangement of mitozolomide (1b) by the hypervalent iodine oxidants iodosobenzene in formic acid or iodobenzene bis(trifluoroacetate) (PIFA) in aqueous acetonitrile, or LTA in acetic acid, have all led to the recovery of unchanged amide. A modified Curtius reaction involving interaction of the carboxylic acid (15b) with diphenylphosphoryl azide (DPPA) $)^{13}$ in $t$-butanol failed to lead to the corresponding $t$-butylurethane of isocyanate (23): only degradation of the bicyclic nucleus was observed.

We have previously shown ${ }^{12}$ that thermal degradation of the tetrazine ring preceeds Curtius rearrangement of the acylazide derivative (21) even in the low boiling anhydrous solvents acetone, chloroform, benzene or toluene, and no 23 was isolated. Attempted Lossen rearrangement of the hydroxamic acid $(22)^{12}$ in refluxing thionyl chloride was also unsuccessful. 
As a last resort the 8-nitroimidazotetrazine $(25)^{5}$ was hydrogenated in 1,4 dioxane over 5\% Pd-charcoal catalyst at atmospheric pressure to yield an unstable brown product. However, its ${ }^{1} \mathrm{H}$ NMR spectrum was not consistent with that expected for the target amine (24): although the methylene triplets were shifted upfield compared to other imidazotetrazines, there was no upfield shift of the imidazole proton at $\mathrm{C}(6)$ in comparison to imidazotetrazines with an EWG at $\mathrm{C}(8)$; also, the presence of a triplet at $\delta 9.5$ indicated that a ringopened product was formed. Clearly, unlike those stable imidazotetrazines with EWGs at C(8) (eg. temozolomide and mitozolomide), the presence of a $+\mathrm{M}$ electron-donating group in 8-aminoimidazotetrazine (24) renders the bicyclic system too unstable to be isolated.

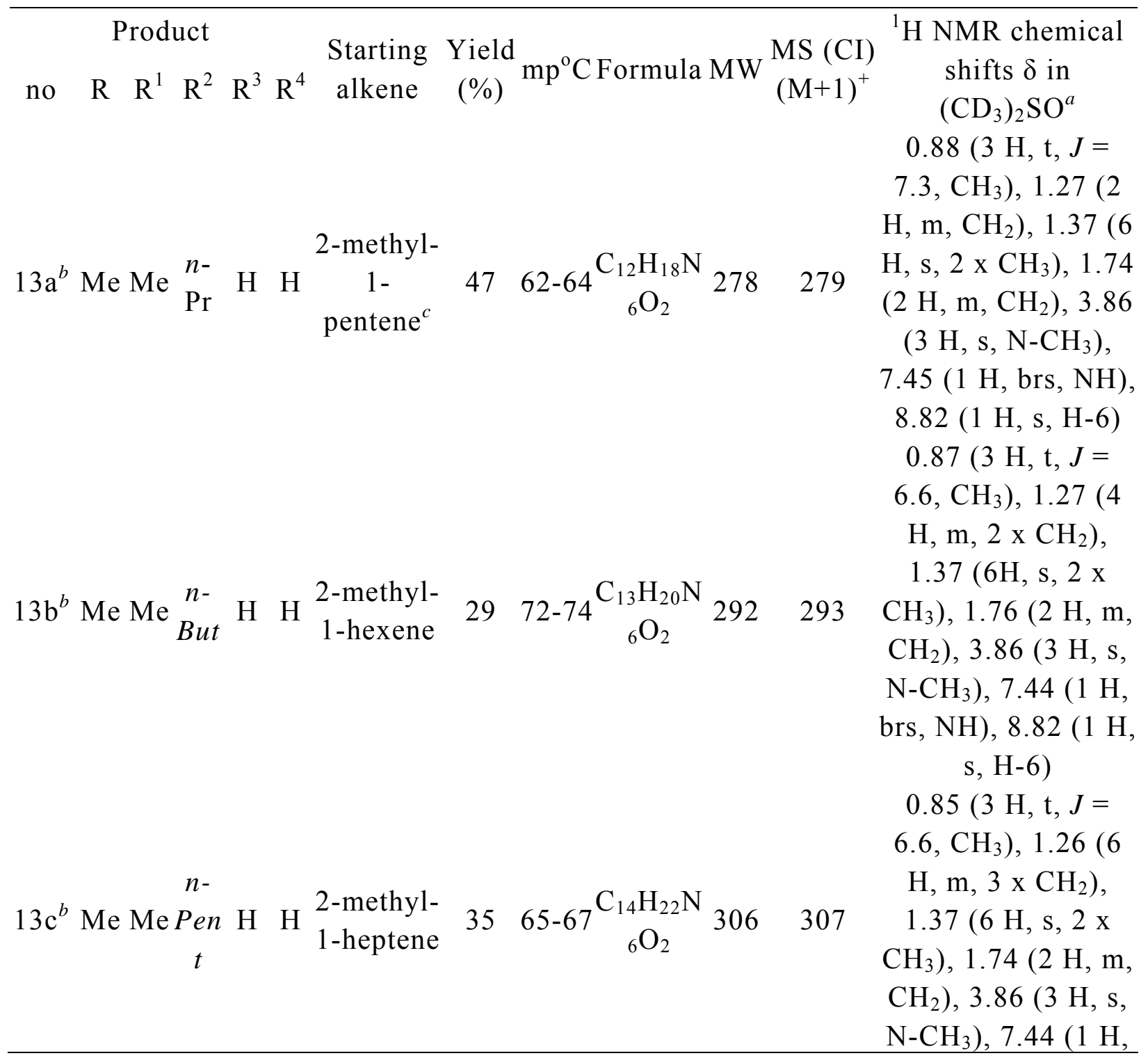




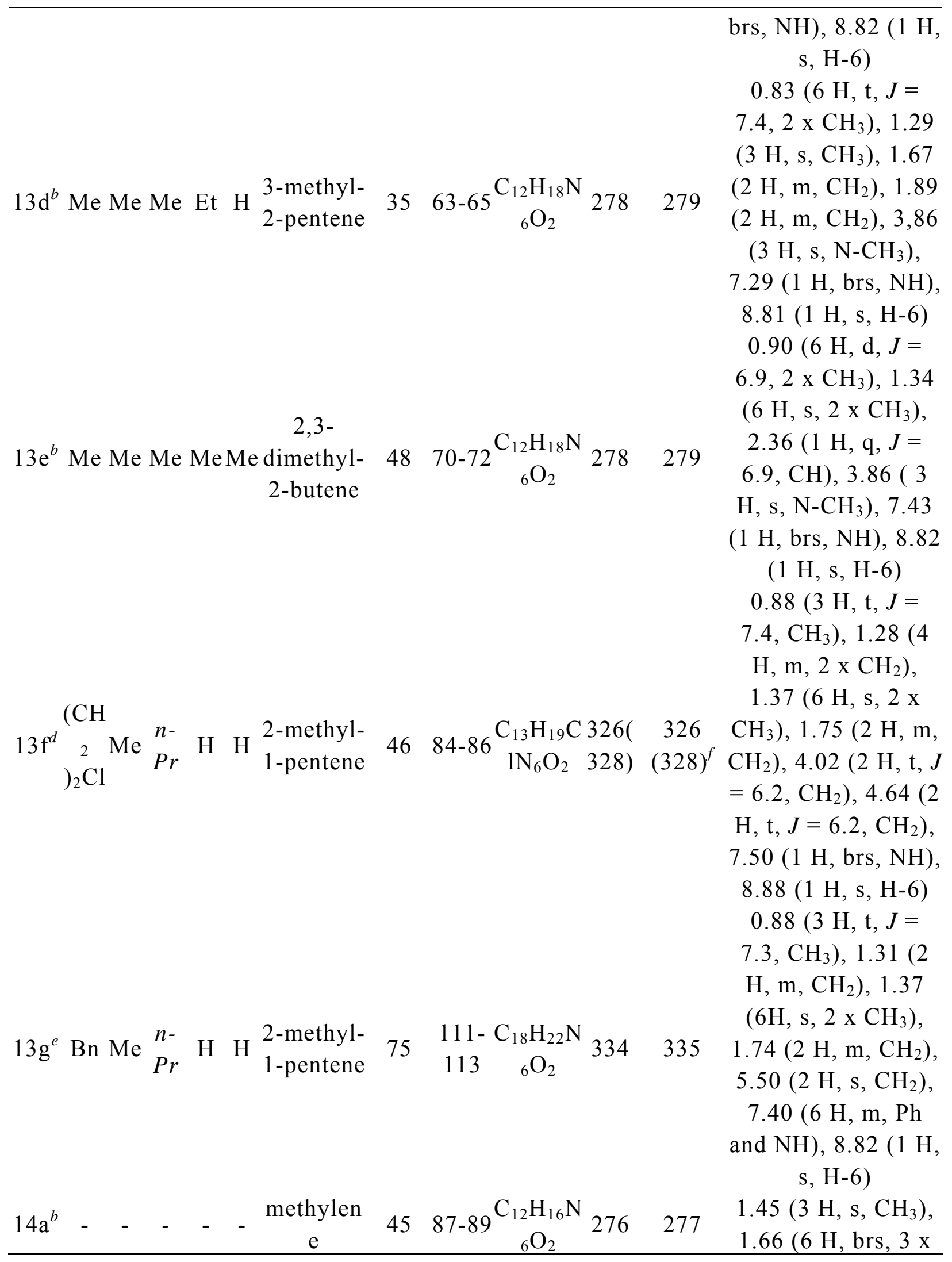




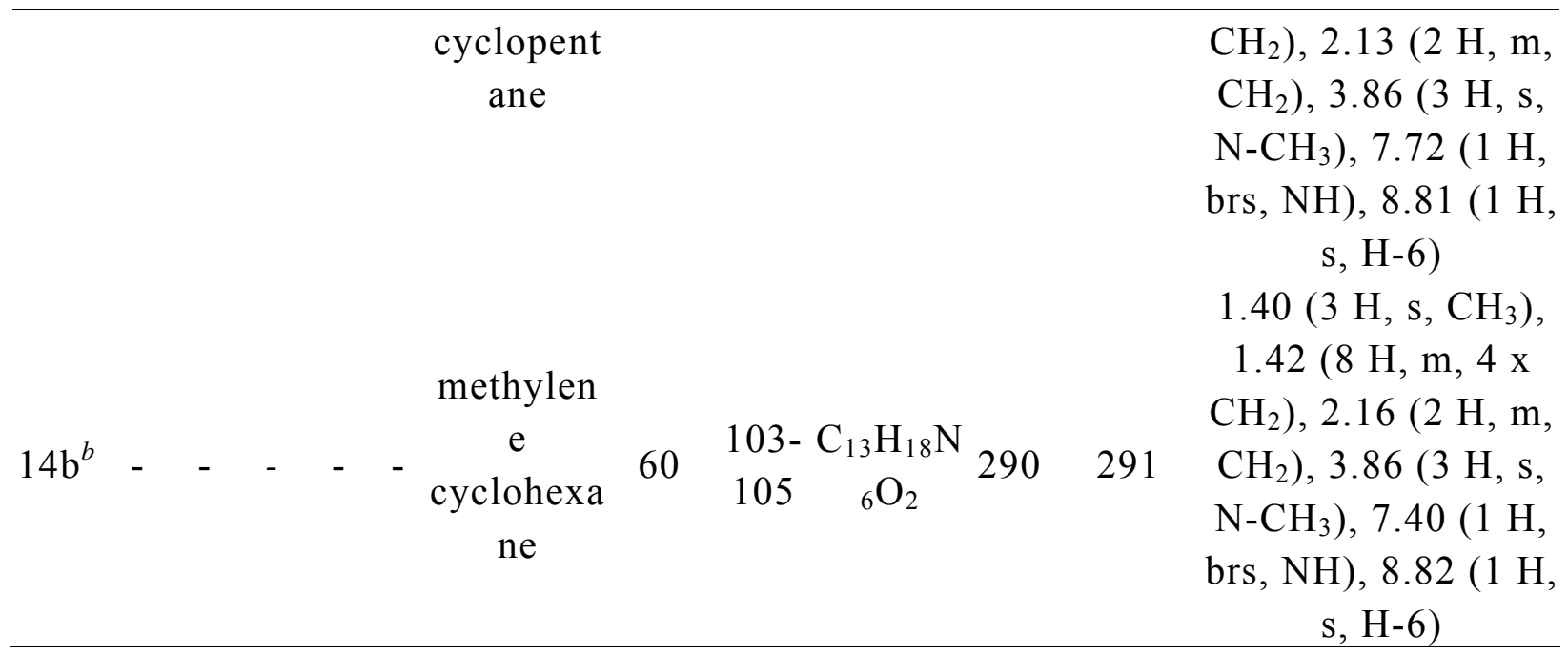

${ }^{a}$ Coupling constants in Hz. ${ }^{b}$ From the cyanoimidazotetrazine (7a). ${ }^{c}$ Also formed (50\% yield) from 2-methyl-2-pentene. ${ }^{d}$ From $(7 \mathrm{~b}) .{ }^{e}$ From $(7 \mathrm{c}) .{ }^{f}$ El mass spectrum.

\section{Experimental Section}

General Procedures. Melting points are uncorrected. ${ }^{1} \mathrm{H}$ and ${ }^{13} \mathrm{C}$ NMR spectra were recorded on a Bruker ARX 250 spectrometer in $\left(\mathrm{CD}_{3}\right)_{2} \mathrm{SO}$ solutions, with $\mathrm{Me}_{4} \mathrm{Si}$ as the internal standard; $J$ values are in $\mathrm{Hz}$. IR spectra were determined on a Mattson 2020 Galaxy Series FT spectrometer as $\mathrm{KBr}$ discs.

8-Cyano-3-methylimidazo[5,1-d]-1,2,3,5-tetrazine-4(3H)-one (7a). Thionyl chloride $(0.2 \mathrm{~mL})$ was added to a stirred suspension of temozolomide (1a) $(0.5 \mathrm{~g})$ in DMF $(5 \mathrm{~mL})$ and the mixture was maintained at $60{ }^{\circ} \mathrm{C}$ for $5 \mathrm{~h}$. The mixture was then concentrated in vacuo and quenched with water. The resulting precipitate was collected and recrystallised from aqueous acetone to yield the cyano-imidazotetrazine $(85 \%)$ as a white solid, $\mathrm{mp} 183-185{ }^{\circ} \mathrm{C}$ (decomp) (lit. ${ }^{9} 185-187{ }^{\circ} \mathrm{C}$ ) with IR, ${ }^{1} \mathrm{H}$ NMR and ${ }^{13} \mathrm{C}$ NMR spectra identical to material prepared (52\%) from 4-cyano-5-diazoimidazole and methyl isocyanate in dry DMSO. ${ }^{9}$ Compound 7 a was also formed $(59 \%)$ from temozolomide and phosphorous oxychloride at $85-90{ }^{\circ} \mathrm{C}$.

To a stirred solution of temozolomide $(0.2 \mathrm{~g})$ in acetonitrile $(2.5 \mathrm{~mL})$ were added formic acid $(0.4 \mathrm{~mL})$ and paraformaldehyde $(0.155 \mathrm{~g})$. The mixture was heated at $65{ }^{\circ} \mathrm{C}$ for $12 \mathrm{~h}$ and the resulting yellow solution was concentrated under reduced pressure to give an oil which was triturated with ethyl acetate. 
The resulting precipitate was collected by filtration and washed with ethyl acetate to yield $7 \mathrm{a}(0.064 \mathrm{~g}, 35 \%)$.

3-(2-Chloroethyl)-8-cyanoimidazo[5,1-d]-1,2,3,5-tetrazine-4(3H)-one (7b). Similarly prepared, from mitozolomide (1b) and thionyl chloride-DMF (49\% yield), the cyano-imidazotetrazine (7b) formed beige crystals, from aqueous acetone, mp 108-110 ${ }^{\circ} \mathrm{C}$ (decomp) (lit. ${ }^{5} 108-110{ }^{\circ} \mathrm{C}$ ), identical to a sample formed from 4-cyano-5-diazoimidazole and 2-chloroethyl isocyanate in dry DMSO. ${ }^{5}$

3-Benzyl-8-cyanoimidazo[5,1-d]-1,2,3,5-tetrazine-4(3H)-one (7c). Similarly prepared, from 3-benzyl-8-carbamoylimidazo[5,1-d]-1,2,3,5-tetrazin-4(3H)one (1c) ${ }^{4}$ and thionyl chloride-DMF, this nitrile (79\% yield) crystallised from aqueous acetone as pale beige crystals; mp $110-115{ }^{\circ} \mathrm{C}$ (decomp); IR ( $\left.\mathrm{KBr}\right)$ 3123, $2243(\mathrm{CN}), 1748(\mathrm{C}=\mathrm{O}), 1738(\mathrm{C}=\mathrm{O}), 1458,1049,895,708 \mathrm{~cm}^{-1} ;{ }^{1} \mathrm{H}$ $\mathrm{NMR}\left[\left(\mathrm{CD}_{3}\right)_{2} \mathrm{SO}\right] \delta=5.54\left(2 \mathrm{H}, \mathrm{s}, \mathrm{CH}_{2}\right), 7.40(5 \mathrm{H}, \mathrm{m}, \mathrm{Ph}), 9.05(1 \mathrm{H}, \mathrm{s}, \mathrm{H}-6)$; ${ }^{13} \mathrm{C}$ NMR $\left[\left(\mathrm{CD}_{3}\right)_{2} \mathrm{SO}\right] \delta=52.74\left(\mathrm{CH}_{2}\right), 108.44(\mathrm{C}-8), 112.79(\mathrm{CN}), 128.25$ (phenyl CH), 128.33 (phenyl CH), 128.73 (phenyl CH), 131.89 (C-6), 135.20 (phenyl C), 138.54 (C-8a), 140.92 (C-4); MS (CI) m/z $253(\mathrm{M}+1)^{+}$. Anal. Calcd for $\mathrm{C}_{12} \mathrm{H}_{8} \mathrm{~N}_{6} \mathrm{O}: \mathrm{C}, 57.14 ; \mathrm{H}, 3.20 ; \mathrm{N}, 33.32$. Found: C, 57.10; H, 3.20; N, 33.29\%.

8-Cyano-3-ethylimidazo[5,1-d]-1,2,3,5-tetrazine-4(3H)-one (7d). Similarly prepared, from 8-carbamoyl-3-ethylimidazo[5,1-d]-1,2,3,5-tetrazin-4(3H)-one $(1 \mathrm{~d})^{4}$ and thionyl chloride-DMF, this nitrile $(25 \%$ yield) crystallised from aqueous acetone as pale beige crystals; mp 50-52 ${ }^{\circ} \mathrm{C}$ (decomp); IR ( $\left.\mathrm{KBr}\right)$ 3142, $2241(\mathrm{CN}), 1740(\mathrm{C}=\mathrm{O}), 1460,1267,1061,949,745 \mathrm{~cm}^{-1}$; ${ }^{1} \mathrm{H}$ NMR $\left[\left(\mathrm{CD}_{3}\right)_{2} \mathrm{SO}\right] \delta 1.40\left(3 \mathrm{H}, \mathrm{t}, J=7.2 \mathrm{~Hz}, \mathrm{CH}_{3}\right), 4.37\left(2 \mathrm{H}, \mathrm{q}, J=7.2 \mathrm{~Hz}, \mathrm{CH}_{2}\right)$, $9.05(1 \mathrm{H}, \mathrm{s}, \mathrm{H}-6) ;{ }^{13} \mathrm{C} \mathrm{NMR}\left[\left(\mathrm{CD}_{3}\right)_{2} \mathrm{SO}\right] \delta 11.60\left(\mathrm{CH}_{3}\right), 43.00\left(\mathrm{CH}_{2}\right), 105.70$ (C-8), 110.62 (CN), 129.31 (C-6), 135.98 (C-8a), 138.74 (C-4); MS (CI) m/z $191(\mathrm{M}+1)^{+}$. Anal. Calcd for $\mathrm{C}_{7} \mathrm{H}_{6} \mathrm{~N}_{6} \mathrm{O}: \mathrm{C}, 44.21 ; \mathrm{H}, 3.18 ; \mathrm{N}, 44.19$. Found: $\mathrm{C}$, $43.93 ; \mathrm{H}, 3.22 ; \mathrm{N}, 44.07 \%$.

\section{1,3-Bis(8-cyano-3,4-dihydro-4-oxoimidazo[5,1-d]-1,2,3,5-tetrazin-3-}

methyl)benzene (8b). This bis(cyanoimidazotetrazine) was prepared from the bis(carboxamide) precursor ( $8 \mathrm{a})^{10}$ and thionyl chloride ( 2 mol. equiv.) in DMF (as above). The product (55\%) had mp 139-141 ${ }^{\circ} \mathrm{C}$ (decomp); IR (KBr) 3127, $2239(\mathrm{CN}), 1751(\mathrm{C}=\mathrm{O}), 1458,1368,1229,1061,743 \mathrm{~cm}^{-1} ;{ }^{1} \mathrm{H}$ NMR $\left[\left(\mathrm{CD}_{3}\right)_{2} \mathrm{SO}\right] \delta 5.54\left(4 \mathrm{H}, \mathrm{s}, 2 \times \mathrm{CH}_{2}\right), 7.39(3 \mathrm{H}, \mathrm{m}$, arom $\mathrm{CH}), 7.55(1 \mathrm{H}, \mathrm{m}$, arom $\mathrm{CH}), 9.08(2 \mathrm{H}, \mathrm{s}, 2 \times \mathrm{H}-6) ;{ }^{13} \mathrm{C} \mathrm{NMR}\left[\left(\mathrm{CD}_{3}\right)_{2} \mathrm{SO}\right] \delta 52.49\left(2 \times \mathrm{CH}_{2}\right)$, 108.10 (2 x C-8), $113.20(2 \times \mathrm{CN}), 127.84,127.87,129.01$ (arom CH), 131.94 ( 2 x C-6), 138.54 ( 2 x C-8a), 140.86 ( 2 x C-4). Anal. Calcd for $\mathrm{C}_{18} \mathrm{H}_{10} \mathrm{~N}_{12} \mathrm{O}_{2}$ : C, 50.71; H, 2.36; N, 39.42. Found: C, 50.66; H, 2.37; N, 39.39\%. 
3-Methyl-8-thiocarbamoylimidazo[5,1-d]-1,2,3,5-tetrazin-4(3H)-one (9). 8Cyano-3-methyl-imidazo[5,1-d]-1,2,3,5-tetrazine-4(3H)-one (7a) (0.5 g) was heated with thioacetamide $(0.4 \mathrm{~g})$ in DMF $(20 \mathrm{~mL})$ saturated with dry $\mathrm{HCl}$ gas at $80-100{ }^{\circ} \mathrm{C}$ for $30 \mathrm{~min}$. The solution was cooled to room temperature and then diluted with water. The aqueous layer was extracted with ethyl acetate; evaporation of the solvent gave a brown oil which was triturated with diethyl ether. The resulting precipitate was collected and washed with diethyl ether to yield 9 as an orange powder $(0.29 \mathrm{~g}, 49 \%)$, mp 165-167 ${ }^{\circ} \mathrm{C}$ (decomp); IR $(\mathrm{KBr}) 3127,1750(\mathrm{C}=\mathrm{O}), 1628,1460,1059,947,648 \mathrm{~cm}^{-1} ;{ }^{1} \mathrm{H}$ NMR $\left[\left(\mathrm{CD}_{3}\right)_{2} \mathrm{SO}\right] \delta 3.86\left(3 \mathrm{H}, \mathrm{s}, \mathrm{CH}_{3}\right), 8.82(1 \mathrm{H}, \mathrm{s}, \mathrm{H}-6), 9.47$ (1 H, br s, NH), 9.94 (1 H, br s, NH); ${ }^{13} \mathrm{C}$ NMR $\left[\left(\mathrm{CD}_{3}\right)_{2} \mathrm{SO}\right]$ d $36.42\left(\mathrm{CH}_{3}\right), 127.98(\mathrm{C}-6), 134.04$ (C-8), 134.80 (C-8a), 139.36 (C-4), $188.03\left(\mathrm{CSNH}_{2}\right) ; \mathrm{MS}(\mathrm{CI}) \mathrm{m} / \mathrm{z} 211$ $(\mathrm{M}+1)^{+}$. Anal. Calcd for $\mathrm{C}_{6} \mathrm{H}_{6} \mathrm{~N}_{6} \mathrm{OS}: \mathrm{C}, 34.28 ; \mathrm{H}, 2.88 ; \mathrm{N}, 39.98$. Found: $\mathrm{C}$, $34.22 ; \mathrm{H}, 2.88$; N, 39.91\%. The same product $(27 \%)$ was formed when 7 a was stirred at $25{ }^{\circ} \mathrm{C}$ with thiolacetic acid (2 mol equiv) in $10 \mathrm{M}-\mathrm{HCl}$ for $12 \mathrm{~h}$.

A mixture of temozolomide $(1 \mathrm{a})(0.2 \mathrm{~g})$ and Belleau's reagent $(0.30 \mathrm{~g})$ in DCM ( $5 \mathrm{~mL}$ ) was stirred at room temperature for $48 \mathrm{~h}$ and then quenched with water. The precipitate was collected by filtration and washed with water, followed by DCM. Recrystallisation of the residue from aqueous acetone yielded 8-thiotemozolomide (9) as an orange powder $(10 \%), \mathrm{mp} 165-167{ }^{\circ} \mathrm{C}$ (efferv), identical to the sample (above).

General method for the Ritter Synthesis of $N$-substituted imidazo[5,1-d]1,2,3,5-tetrazine-8-carboxamides (13) and (14)

To a solution of the appropriate 8-cyanoimidazotetrazine (7) $(0.3 \mathrm{~g})$ in acetic acid $(5 \mathrm{~mL})$ containing concentrated $\mathrm{H}_{2} \mathrm{SO}_{4}(0.1 \mathrm{~mL})$ was added the alkene (10) (1.2 mol equiv) and the mixture was stirred at $25{ }^{\circ} \mathrm{C}$ for $12 \mathrm{~h}$. The mixture was diluted with water, stirred at $25{ }^{\circ} \mathrm{C}$ for $2 \mathrm{~h}$, and products were collected. Yields and physical properties of $N$-substituted imidazotetrazinecarboxamides are listed in Table.

3,4-Dihydro-4-oxo-3-methylimidazo[5,1-d]-1,2,3,5-tetrazine-8-

carbohydrazide hydrochloride salt (17). A mixture of the carboxylic acid $(15 \mathrm{a})(1.0 \mathrm{~g})$ and $t$-butylcarbazate $(0.74 \mathrm{~g})$ were coupled in the presence of PyBOP $(2.2 \mathrm{~g})$ in acetonitrile $(40 \mathrm{~mL})$ containing triethylamine $(1.0 \mathrm{~mL})$ for $24 \mathrm{~h}$ at $25{ }^{\circ} \mathrm{C}$. Vacuum evaporation of the mixture gave an oil which was purified by flash chromatography using EtOAc as eluent. Extraction of the product into $1 \mathrm{M}-\mathrm{HCl}$, followed by vacuum concentration, furnished the carbohydrazide hydrochloride $(0.5 \mathrm{~g}, 40 \%)$, mp $160{ }^{\circ} \mathrm{C}$ (decomp); IR (KBr) 3260, 3173, $3100(\mathrm{NH}), 2800-3100\left(\mathrm{NH}_{3}{ }^{+}\right), 1721(\mathrm{C}=\mathrm{O}), 1674 \mathrm{~cm}^{-1} ;{ }^{1} \mathrm{H} \mathrm{NMR}$ 
$\left[\left(\mathrm{CD}_{3}\right)_{2} \mathrm{SO}\right] \delta 3.86\left(3 \mathrm{H}, \mathrm{s}, \mathrm{CH}_{3}\right), 4.62\left(3 \mathrm{H}, \mathrm{s}, \mathrm{NH}_{3}{ }^{+}\right), 8.83(1 \mathrm{H}, \mathrm{s}, \mathrm{H}-6), 9.70$ $(1 \mathrm{H}, \mathrm{s}, \mathrm{NH})$. Anal. Calcd for $\mathrm{C}_{6} \mathrm{H}_{8} \mathrm{ClN}_{7} \mathrm{O}_{2}: \mathrm{C}, 29.34 ; \mathrm{H}, 3.28 ; \mathrm{N}, 39.92$. Found: C, 29.60; H, 3.26; N, 40.39\%.

3-(2-Chloroethyl)-3,4-dihydro-4-oxoimidazo[5,1-d]-1,2,3,5-tetrazine-8carbohydrazide trifluoroacetate salt (17). The carboxylic acid (15b) (3.0 g) and $t$-butylcarbazate $(1.79 \mathrm{~g})$ in acetonitrile-triethylamine were coupled as above. After removal of solvent the residue was dissolved in EtOAc $(20 \mathrm{~mL})$ and the solution was shaken with $1 \mathrm{M}-\mathrm{HCl}(20 \mathrm{~mL})$. The protected hydrazide (16b) (3.18 g, 80\%) was collected, mp 108-109 ${ }^{\circ} \mathrm{C}$ (decomp); IR (KBr) 3449, 3349 and $3187(\mathrm{NH}), 1735(\mathrm{C}=\mathrm{O}), 1669 \mathrm{~cm}^{-1} ;{ }^{1} \mathrm{H}$ NMR $\left[\left(\mathrm{CD}_{3}\right)_{2} \mathrm{SO}\right] \delta 1.44(9$ $\left.\mathrm{H}, \mathrm{s}, 3 \times \mathrm{CH}_{3}\right), 4.03\left(2 \mathrm{H}, \mathrm{t}, J=6.0, \mathrm{CH}_{2} \mathrm{Cl}\right), 4.65\left(2 \mathrm{H}, \mathrm{t}, J=6.0, \mathrm{NCH}_{2}\right), 8.93$ (1 H, s, H-6), 8.97 (2 H, s, NH).

The hydrazide (16b) (1.24 g) was deprotected in a solution of TFA/triethylsilane/triisopropylsilane (95: 2.5: 2.5) $(20 \mathrm{~mL})$ at $25{ }^{\circ} \mathrm{C}$ for $2 \mathrm{~h}$. Solvent was removed and product precipitated with diethyl ether. The collected hydrazide was dissolved in water $(5 \mathrm{~mL})$, frozen and lyophilised, yielding pure trifluoracetate salt (16b) as a cream solid $(0.95 \mathrm{~g}, 77 \%), \mathrm{mp}$ $127^{\circ} \mathrm{C}$ (decomp); IR (KBr) 3325 and $3270(\mathrm{NH}), 2800-3100\left(\mathrm{NH}_{3}{ }^{+}\right), 1750$ $(\mathrm{C}=\mathrm{O}), 1674 \mathrm{~cm}^{-1} ;{ }^{1} \mathrm{H}$ NMR $\left[\left(\mathrm{CD}_{3}\right)_{2} \mathrm{SO}\right] \delta 4.04\left(2 \mathrm{H}, \mathrm{t}, J=6.0, \mathrm{CH}_{2} \mathrm{Cl}\right), 4.66$ $\left(2 \mathrm{H}, \mathrm{t}, J=6.0, \mathrm{NCH}_{2}\right), 8.96(1 \mathrm{H}, \mathrm{s}, \mathrm{H}-6), 8.97(1 \mathrm{H}, \mathrm{s}, \mathrm{NH})$.

Synthesis of hydrazones (19). To a solution of the carbohydrazide (18) $(0.6 \mathrm{~g})$ in water $(10 \mathrm{~mL})$ was added 2-chlorobenzaldehyde $(0.3 \mathrm{~g})$ and sodium acetate $(0.9 \mathrm{~g})$. The mixture was stirred at $25{ }^{\circ} \mathrm{C}(24 \mathrm{~h})$ and product was collected and washed with aqueous acetonitrile. The hydrazone (19a) was crystallised from EtOAc as a yellow solid, mp 162-164 ${ }^{\circ} \mathrm{C}$ (decomp); IR (KBr) 3277 and $3094(\mathrm{NH}), 1736(\mathrm{C}=\mathrm{O}), 1690(\mathrm{C}=\mathrm{O}), 1574 \mathrm{~cm}^{-1} ;{ }^{1} \mathrm{H}$ NMR $\left[\left(\mathrm{CD}_{3}\right)_{2} \mathrm{SO}\right] \delta=4.05\left(2 \mathrm{H}, \mathrm{t}, J=7.5, \mathrm{CH}_{2} \mathrm{Cl}\right), 4.68\left(2 \mathrm{H}, \mathrm{t}, J=7.5, \mathrm{NCH}_{2}\right)$, $7.47(3 \mathrm{H}, \mathrm{m}, 3 \mathrm{x}$ aryl-H), $8.05(1 \mathrm{H}, \mathrm{m}$, aryl-H), $9.04(1 \mathrm{H}, \mathrm{s}, \mathrm{H}-6), 9.05(1 \mathrm{H}$, $\mathrm{s}$, hydrazone $\mathrm{C}-\mathrm{H}), 12.43(1 \mathrm{H}, \mathrm{s}, \mathrm{NH})$; MS (FAB) $\mathrm{m} / \mathrm{z} 380\left(\mathrm{M}+\mathrm{H}^{+}\right)$.

Similarly prepared was the hydrazone (19b), from 4-chlorobenzaldehyde in $86 \%$ yield, mp 180-182 ${ }^{\circ} \mathrm{C}$ (decomp); IR ( KBr) 3468, $3316(\mathrm{NH}), 1746(\mathrm{C}=\mathrm{O})$, $1692(\mathrm{C}=\mathrm{O}), 1574 \mathrm{~cm}^{-1} ;{ }^{1} \mathrm{H}$ NMR $\left[\left(\mathrm{CD}_{3}\right)_{2} \mathrm{SO}\right] \delta 4.05\left(2 \mathrm{H}, \mathrm{t}, J=6.0, \mathrm{CH}_{2} \mathrm{Cl}\right)$, $4.67\left(2 \mathrm{H}, \mathrm{t}, J=6.0, \mathrm{NCH}_{2}\right), 7.65(4 \mathrm{H}, \mathrm{m}, 4 \mathrm{x}$ aryl-H $), 8.60(1 \mathrm{H}, \mathrm{s}$, hydrazone $\mathrm{C}-\mathrm{H}), 9.01(1 \mathrm{H}, \mathrm{s}, \mathrm{H}-6), 9.05(1 \mathrm{H}, \mathrm{s}$, hydrazone $\mathrm{C}-\mathrm{H}), 12.12(1 \mathrm{H}$, $\mathrm{s}, \mathrm{NH})$; $\mathrm{MS}(\mathrm{FAB}) \mathrm{m} / \mathrm{z} 380\left(\mathrm{M}+\mathrm{H}^{+}\right)$; and $19 \mathrm{c}$, from 3-nitrobenzaldehyde in $35 \%$ yield, $\mathrm{mp} 176-178{ }^{\circ} \mathrm{C}$ (decomp); IR ( KBr) 3312 and $3125(\mathrm{NH}), 1750$ $(\mathrm{C}=\mathrm{O}), 1695(\mathrm{C}=\mathrm{O}), 1574,1515$ and $1358\left(\mathrm{NO}_{2}\right) \mathrm{cm}^{-1} ;{ }^{1} \mathrm{H}$ NMR $\left[\left(\mathrm{CD}_{3}\right)_{2} \mathrm{SO}\right] \delta$ $4.04\left(2 \mathrm{H}, \mathrm{t}, J=6.0, \mathrm{CH}_{2} \mathrm{Cl}\right), 4.67\left(2 \mathrm{H}, \mathrm{t}, J=6.0, \mathrm{NCH}_{2}\right), 7.77(1 \mathrm{H}, \mathrm{m}$, aryl$\mathrm{H}), 8.15(1 \mathrm{H}, \mathrm{m}$, aryl-H), $8.29(1 \mathrm{H}, \mathrm{m}$, aryl-H), $8.54(1 \mathrm{H}$, s, aryl H-2'), 8.72 
(1 H, s, hydrazone C-H), 9.04 (1 H, s, H-6), 12.36 (1 H, s, NH); MS (FAB) $\mathrm{m} / \mathrm{z} 391\left(\mathrm{M}+\mathrm{H}^{+}\right)$. Anal. Calcd for $\mathrm{C}_{14} \mathrm{H}_{11} \mathrm{ClN}_{8} \mathrm{O}_{4}: \mathrm{C}, 43.03 ; \mathrm{H}, 2.84 ; \mathrm{N}, 28.68$. Found: C, 42.79; H, 2.65; N, 28.41\%.

\section{Acknowledgements}

Financial support from Schering-Plough Research Institute, Kenilworth, New Jersey (to D.A.F.L. and J.A.) and the Cancer Research Campaign, UK (to M.F.G.S.) is acknowledged.

\section{References}

1. Newlands, E. S.; Stevens, M. F. G.; Wedge, S. R.; Wheelhouse, R. T.; Brock, C. Cancer Treatment Rev. 1997, 23, 35.

2. Denny, B. J.; Wheelhouse, R. T.; Stevens, M. F. G.; Tsang, L. L. H.; Slack, J. A. Biochemistry 1994, 33, 9045.

3. Newlands, E. S.; Blackledge G.; Slack, J. A.; Goddard, C.; Brindley, C. J.; Holden, L.; Stevens, M. F. G. Cancer Treatment Rep. 1985, 69, 801. (b) Harding, M.; Docherty, V.; Mackie, R.; Dorward, A.; Kaye, S. Eur. J. Clin. Oncol. 1989, 25, 785. (c) Schornagel, J. H.; Simonetti, G.; Dubbelman, R.; ten Bokkel Huinink, W. W.; McVie, J. G. Cancer Chemother. Pharmacol. 1990, 26, 237.

4. Stevens, M. F. G.; Hickman, J. A.; Langdon, S. P.; Chubb, D.; Vickers, L.; Stone, R.; Baig, G.; Goddard, C.; Gibson, N. W.; Slack, J. A.; Newton, C.; Lunt, E.; Fizames, C.; Lavelle, F. Cancer Res. 1987, 47, 5846.

5. Lunt, E.; Newton, C. G.; Smith, C.; Stevens, G. P.; Stevens, M. F. G.; Straw, C. G.; Walsh, R. J. A.; Warren, P. J.; Fizames, C.; Lavelle, F.; Langdon, S. P.; Vickers, L. M. J. Med. Chem. 1987, 30, 357.

6. Clark, A. S.; Deans, B.; Stevens, M. F. G.; Tisdale, M. J.; Wheelhouse, R. T.; Denny, B. J.; Hartley, J. A. J. Med. Chem. 1995, 38, 1493.

7. Arrowsmith, J.; Jennings, S. A.; Stevens, M. F. G. Unpublished work.

8. Arrowsmith, J.; Missailidis, S.; Stevens, M. F. G. Anti-Cancer Drug Design 1999, 14, 205.

9. Wang, Y.; Stevens, M. F. G.; Chan, T-M.; DiBenedetto, D.; Ding, Z-X.; Gala, D.; Hou, D.; Kugelman, M.; Leong, W.; Kuo, S-C.; Mas, J. L.; 
Schumacher, D. P.; Schutts, B. P.; Smith, L.; Zhan, Z-Y. J. J. Org. Chem. 1997, 62, 7288.

10. Wang, Y.; Wheelhouse, R. T.; Zhao, L.; Langnel, D. A. F.; Stevens, M. F. G. J. Chem. Soc., Perkin Trans.1 1998, 1669.

11. Heck, M-P.; Wagner, A.; Mioskowski, C. J. Org. Chem. 1996, 61, 6486.

12. Horspool, K. R.; Stevens, M. F. G.; Newton, C. G.; Lunt, E.; Walsh, R. J. A.; Pedgrift, B. L.; Baig, G. U.; Lavelle, F.; Fizames, C. J. Med. Chem. 1990, 33, 1393.

13. Ninomiya, K.; Shioiri, T.; Yamada, S. Tetrahedron 1974, 30, 2151. 